\title{
SOCIAL NETWORKING SERVICE USING JAPAN TYPE TRADITIONAL COMMUNITY NETWORK
}

\author{
Hiroshi WASAKI
}

University oh Hyogo Graduate School oh Human Science and Environment, 1-1-12 shinzaikehonmachi, Himeji-shi, Hyogo, 670-0092, Japan

\begin{abstract}
The activity of "Local community SNS" is now in the limelight for the reason it is effective to the local revitalization, However, not a few "Local Community SNS Sites" are now in the "landing state", and are deadlocked at the management, In this thesis, I introduce the design concept and the applying method of "Our Local community SNS" succeeded in developing by using the interdisciplinary study or tying up the knowledge of variegated scientific research, Furthermore, clarify the sustainability of "Our local community SNS" obtained through the social experiment,
\end{abstract}

Keywords : Community network, Local community SNS, social captal, KOU

\section{1.は じめに}

平成 19 年度版国民生活白書のタイトルは「つながりが築 く豊かな国民生活」である。白書は，生活全般に対して満足 している人の割合が低下していることを指摘し，国民が物質 的豊かさから精神的豊かさを求める方向にシフトしていると しつつ, 昨今, 精神的やすらぎと生活の豊かさをもたらす「つ ながり」が徐々に希薄化しており，その再生が急務であると 述べている，従来からあった地域や家族の相互の結びっきや 絆，そして相互扶助の意識や信頼が崩れ，コミュニティの中 では個々の生活における疎外化や孤立化が急速に強まってき ていることへの危機感を提起している.

1995 年 1 月の阪神淡路大震災では, 避難所となった小学 校等の施設で，希薄化したと言われていた地域のつながりが しばらく実体化した．ライフラインを停止させるような大規 模な自然災害が起こると，被災後 100 時間から 1000 時間に かけて，避難所全体が充足感で満たされる期間が出現する. 東アジア地域においてみられる災害ユートピア (disaster utopia）である。この現象は，満足に供給されない食べ物を 分け合うなど，誰もが弱者に手を差しのべて生きるために助 け合うことで，消えかけていると考えられていたつながりが 復興する可能性を持っていることを表している，古くから日 本の地域社会を支えてきた住民の絆は，「個人主義の台頭や 徹底した西洋化の浸透による地域環境の変化によって消失し たのではなく，沈潜化して見えなくなっていた」［1］だけ なのである

本論では，「地域住民の関係性の可視化と活性化に役立つ と期待されている地域 SNS」[2] の現状と課題について紹
介するとともに, 感性工学的視点から求める関係性価值創造 の手法として ICT と伝統的な日本型地域ネットワークを融 合的に応用することが効果的であることを，新たに筆者が開 発した地域 SNS エンジン「OpenSNP ${ }^{1}$ (オープンエスエヌ ピー)」の効果から考究するとともに, 全国各地の地域 SNS

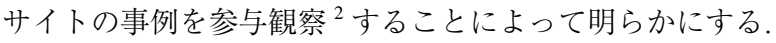

\section{2. 静かに広がるまちおこしの SNS}

参加者が互いに友人を紹介しあい，ネット上で交友関係を 広げるコミュニティ型ウェブサイト・SNS（ソーシャルネッ トワーキング・サービス)，この仕組みを応用し，住民の見え ないつながりを可視化することで，地域掞こしや防犯・防災 情報の発信などという従来の SNS にはない目的や特色を備え た地域限定型の取り組みが，いま全国各地に広がっている。

SNS は一般に会員の招待がないと参加ができず（招待 制)，参加者は名前や住所などのプロフィールを事前に登録 する必要がある。日本では一千万人以上の会員を擁する mixi（ミクシイ）が有名だが，米国には二億人が登録してい る MySpace（マイスペース）があるほど，現在では広く世 界中で多数の人々が利用している.

しかし, SNS もサイト全体が巨大化するにつれて, イン ターネットの負の部分が顕在化し，生命や財産を脅かすなど 危険な状況が目立ってくる。「荒らし」「祭り」「炎上」と呼 ばれるようなネット特有の現象に止まらず，詐欺や薬物，自 殺など青少年を巻き込んだ犯罪にまで広がり，米国議会では 若年者を交流型サイトから守る趣旨の法案（通称 MySpace 法）が提出されたり, mixiでも事件や事故が多発しており, 大規模 SNS サイトの信頼性は急速に低下している。 


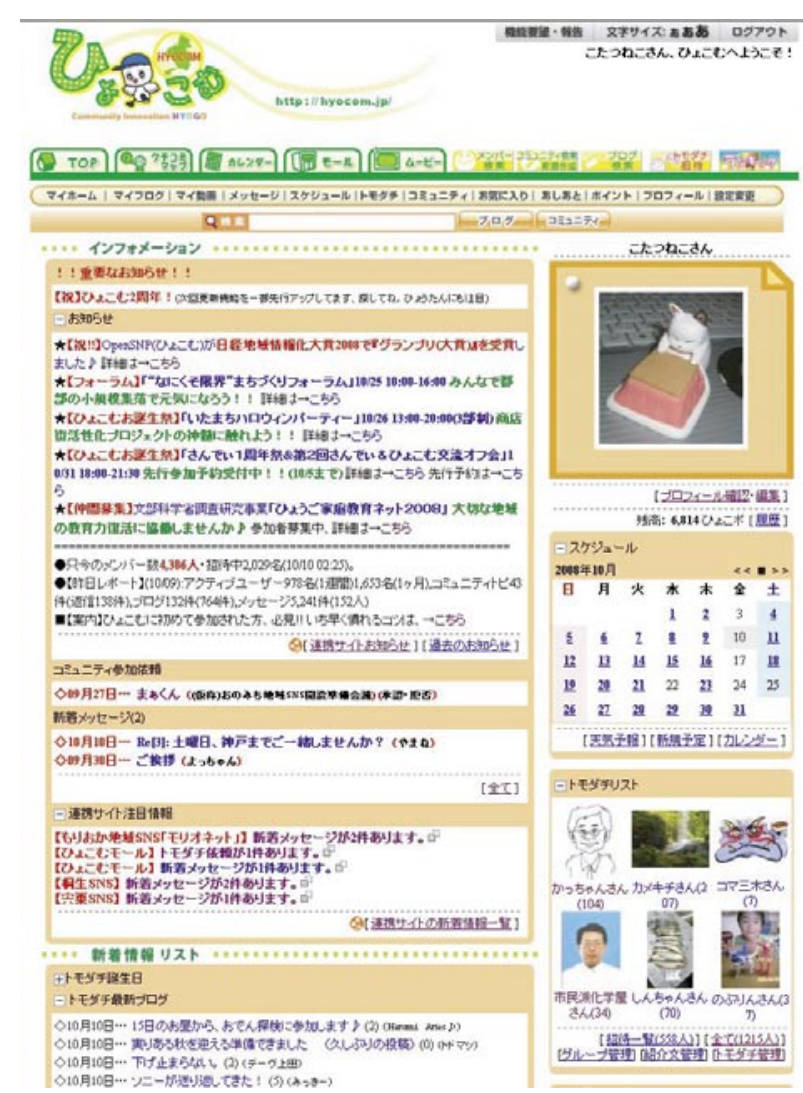

図 1 地域 SNS「ひょこむ」のトップページ

\section{3. 地域 SNS の特徵とメリット}

地域 SNS は, 地域性を活かして信頼できる人の関係をつ なぎながら，外部のインターネットからは閉鎖された状況を 作り，内部からは発信する情報に応じてアクセス制御ができ るなど「ほどよい閉鎖性を保ったネットワーク」環境を成立 させることで, インターネットの悪しき特性を排除し, 安心・ 安全なサイト環境を提供しているものが少なくない. 会員の 大半は直接交流できる地域に住んでいるので, 会員同士が対 面する機会が極めて多い，ネット社会の「出会い系」のよう に仮想空間での交流だけを楽しむのではなく，一緒に地域活 動に参加したり，オフ会と呼ばれるイベントで意気投合した り，互いの経験や人脈を使って支え合ったりして，実社会と ネットを上手に融合させながら，自分自身を高めることがで きる. 2008 年 2 月段階で 336 サイトの地域 SNS が確認さ れている [3].

地域 SNS は, インターネットを使っていながらも実社会 との距離が非常に近いので, 架空や虚偽の人格で利用するこ とは難しい，併せて, 実名登録や招待制を徹底させるなど比 較的厳しい運用ルールを設けているので会員同士の信頼感が 醇成されており，「2ちゃんねる」3 等で話題となる匿名性の 高いネット社会特有の現象はほとんど見られない.（実名性 の確保と匿名性の排除)

また，もともと SNS は個人と個人が繋がる仕組みとして 設計されているが, OpenSNPでは個人とグループやグルー プ同士の連携が生まれやすい機能を実装している，全体で共
有できる地図やカレンダーは, 知らず知らずのうちに協働意 欲を起こさせたり, 便利なグループウェア機能は地域活動の 活性化に一役買っている.（グループウェアとの融合）

このように，信頼性の高い環境の下で，地域活動に積極的 にコミットした住民たちが交流する地域 SNS の利用者は, 行政にとっても格好のパートナーとなる可能性を持ってい る. 地域 SNS の原点である熊本県八代市の「ごろっとやっ ちろ」は，市民向けの電子掲示板を交流サイトに衣替えした 結果, 絶好の広報基盤になったといわれている。兵庫県と OpenSNPのリーディングサイト ${ }^{4}$ である兵庫県域の地域 SNS「ひょこむ」では, 交流型パブリックコメントの実施, 委員会・審議会での利用, 官民協働の研究活動の基盤など, 単なる広報広聴の域を越えた連携の取り組みが実証実験 ${ }^{5} の$ 中で深まっている.

\section{4. 地域 SNS の現状と課題}

わが国の地域 SNS サイトの平均参加者数は, 1,328 人で あるが, これは規模の大きなサイトに引き上げられている傾 向が強い. その分布を見ると 400 人以下が最も多く, つい で 800 人以下となり，これが全体の 6 割を占めている。大 規模なサイトでも，その参加者数は佐賀県の「ひびの」の 8,680 人, 福岡県の「VARRY」の 5,816 人, 兵庫県の「ひょ こむ」の 3,995 人(いずれも 2008 年 7 月現在)となっており, mixi 内最大の地域コミュニティ「I Love Yokohama」の約 5 万人と比較してもひと椼少ないのが現状である [4].

サイトの持続可能性を維持するためには「にぎわい」の継 続が不可欠である。一概に参加者数だけで評価することはで

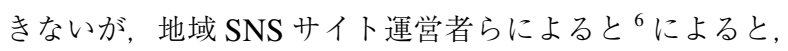
数百人規模のサイトでは運営者自身が相当の努力をしなけれ ばサイト内でのにぎわいを創り出すことは難しく, 一千人を 超えたあたりから自律したコミュニケーションの活性が実現 したという. また, ユーザ数が十万人にもなると, 規模が大 きくなりすぎて, システムの運用管理だけでなく, 地域 SNS の「ほどよい閉鎖性」という特質が活かせなくなるこ とから, 幅は広いが数千から数万人の間が適切な参加者数な

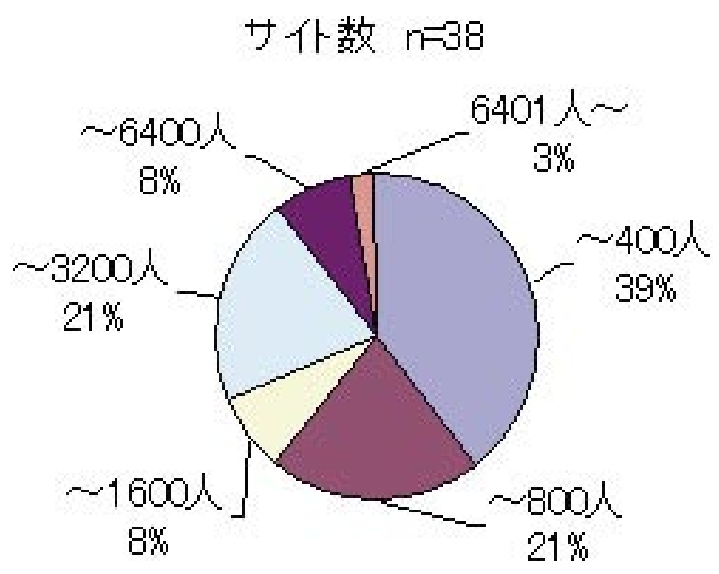

図 2 地域 SNS の規模別サイト分布（筆者が作図） 
のであろうと考えられる．しかし現在は，まだ半数以上のサ イトがその域に達してはいない.

若者中心の mixi と比べて, 平均年齢が高いことも地域 SNS の特徵である. mixi の場合, 35 歳未満の利用者がパソ コンで 8 割, 携帯電話からの 9 割以上を占め, その平均は 28 歳前後である [5]. これに対して筆者による SNS サイト の調査では,「ひょこむ」(兵庫県 3,995 人) は 43.5 歳, 「か ちねっと」(葛飾区 549 人) では 47.3 歳,「ハマっち!」（横 浜市 1,551 人) でも 39.0 歳（いずれも 2008 年 7 月現在）と, mixi とは一回り以上の違いがある. 携帯電話からの利用も 僅か数パーセントに止まっている。また女性が 6 割を占め る mixi に対して，ほとんどの地域 SNS は男性が多数で，そ の比率はほぼ 2 対 1 のものが多い.これは, 個人的なつな がりを求める mixi と異なり, 地域 SNS が「まちづくり」な どの具体的な目的を明確にしていることが，テーマに関心の あるより高い年齢層の仲間達を招待しているからであろうと 推測される。 また, 地域 SNS の運営者は圧倒的に男性が多 く, 彼らは比較的声が掛けやすい同性の年少者を勧誘する傾 向があることから, 男性中心のつながりが反映され, また運 営者の年齢はサイト平均より高くなっていると見られる。

平均年齢が高く男性が多いという特徽は負の要因ではな く, サイト内のコミュニケーションに良い効果を与えてい る. 総じて地域 SNS の書き込みは社会性が高く, 文脈も文 法もしっかりした文章が多い. また, 古くはパソコン通信時 代からネットコミュニティに馴染んだ人がいて, 情報通信の 知見だけでなくネットのモラルや倫理についても詳しく, 他 の参加者を緩やかにリードする指南役として活躍している事 例が, 多数の地域 $\mathrm{SNS}^{7}$ で見られる. その結果として地域 SNS では, 落ち着いた支え合いの雲囲気の交流の場が成立 して，利用者に快適な環境を提供しているのである.

国領二郎・慶応大学教授は, ネットワーク上で多様な主 体が自発的に相互作用を行う「情報プラットホームは, 情報 インフラの物理基盤の上に, 語彙, 文法, 文脈, 規範を共有 する言語空間が主体間の相互作用を支えるコミュニケーショ ン基盤として構成され，その上で発信·共鳴·伝達が偶発（創 発）的な協働を誘発する」［6］としているが, 限定的な地 域ではなくこの環境を一般的に実現している社会モデルはま だ出現していない，地域情報化の進展に伴って普及したブ ロードバンド・インターネットの環境が情報インフラとして 機能し, 相互の信頼関係と地域への愛着という共有意識の上 に現実社会とネット社会の融合的空間を創り出す地域 SNS は, 情報プラットホームの基盤環境を構築するのに大変適し ていると言える。

\section{5. 伝統的な日本型地域ネットワークの智慧}

「昔の日本は夕テ社会だ」とよく言われているが，実はそ れと並んで自発的に結ばれる地域のヨコのつながりである 「仲間」のネットワークが存在していて, これが緩やかにコ ミュニティの持続可能性を醸成してきた。従来,「縁」によ
る支え合いでバランスを取りながら生きてきた人間関係は, 20 世紀になって日本に出現した近代化の思想や，他の力に 頼らず個別で自由に生きることを是とする考え方の広がりに よって，「縁」を「しがらみ」とみなすようになり，自由で 便利な生活を求続ける人たちによって縁が切れていき, 地 域コミュニティとともにばらばらになってしまった [7].

伝統的な日本型地域ネットワークの原点は, 奈良時代の「神 仏習合」における「講」の成立にあると言われている。まっ たく別の宗教的存在であった神社が仏閣を受け入れるにあ たって，豪族のみならず住民が資材や資金を出し合って仏堂 を建立したのである，その後，コミュニティ全体の大事業の 度に「講」がたつようになる。最初は地域全体で助け合う経 済講として生まれた仕組みが,より暮らしに身近な「無尽講」 や「頼母子講」など経済的互助組織として存在になったり, 支え合いの「結」講やコミュニティにおける環境バランスを 保つための「嫁講」「観音講」「無礼講」「契約講」など, 各 地の実情にあわせて変化して生活に取り込まれていった。

さまざまな目的と形態を持つ講には, 日常のヨコネット ワークとして機能するために，（表 1）のような特徴を備え ていた。これらのつながりは，まだ便利な情報通信技術がな かった時代に，主にご近所のクチコミによって「ほどよい閉 鎖性を保つネットワーク」が十分に機能していた，現在，地 域社会の絆感の衰失がもたらす地域環境の悪化が問題とされ ている中で, その解決手法の考え方にわたしたちの先祖が磨 き上げた智慧の活用を検討することは，重要な気づきを与え てくれることとなった

\section{6. 地域 SNS の設計と開発への応用}

全国各地に地域 SNS が誕生し始めた 2006 年 1 月，東京 品川でCAN フォーラムが主宰する「地域 SNS を考えるセ ミナー」 ${ }^{8}$ が開催された。地域 SNS の最新情報を主宰者や 開発者が直接発表・意見交換する初めての機会だった。国領 教授によるパネルトークで, 20 代後半から 30 代前半の若手 実践者たちが生き生きと地域のビジョンを語る姿が印象的 だった。

しかし，同じパネルに並びながらも，二回りほど年長の筆

表 1 伝統的な日本型地域ネットワークの特徵（岡田, 2008）

\begin{tabular}{|c|l|}
\hline ブロジェクト性 & $\begin{array}{l}\text { 明確な目的を持って集まり, 成就の暁には } \\
\text { 解散する }\end{array}$ \\
\hline 自発性 & $\begin{array}{l}\text { 自らが縁を結ぶことを申し出, 関係性の継 } \\
\text { 続を図る }\end{array}$ \\
\hline 定日性 & $\begin{array}{l}\text { 定期的集会を行し, ネットワークを更新し } \\
\text { 結びつきを強化する }\end{array}$ \\
\hline 柔軟性 & $\begin{array}{l}\text { 目的達成のためのルール変更を容認, 組織 } \\
\text { は柔軟でメンバは固定不変でない }\end{array}$ \\
\hline 越境性 & $\begin{array}{l}\text { 宗派, 経済格差, 身分を越え, また村落な } \\
\text { ゙゙地理的境界をも越えることがある }\end{array}$ \\
\hline 閉鎖性 & $\begin{array}{l}\text { ただしメンバ更新の可能性を持ち, 適度に } \\
\text { 居心地良く閉じている }\end{array}$ \\
\hline 入れ子 \\
構造
\end{tabular}


者には単に年齢差だけではない, 違和感があった。総じて他 のパネリストたちの考え方は「個人が繋がれば場が創発す る」という文脈が主流であり, SNS のシステム自体も「個 人と個人をつなぐ」ことのみを前提に設計・運用されていた. 筆者は, 個人間の接続で終始させるのではなく, 持続可能な SNS のモデルを構築するには「個と場, 場と場」のつなが りを可視化することが不可欠であると考えていた，そのため には, 前章で述べた伝統的な日本型地域ネットワークの特徵 や, 利用者相互の「信頼」や特定の地域に対する「愛着」と いう感性的な要素を, しっかりとシステムや運用方法に導入 することが必要で, 当時企画していた地域 SNS のシステム をプログラムが無償公開されている「オープンソース」のプ ログラム 9 ではなく, 自由なアイデアを自在に実現できる新 たな独自のプログラムを開発することとした。 これが, $\lceil$ OpenSNP」と名付けられた独自のSNS エンジンであり, 兵庫県域の地域 SNS サイト「ひょこむ」となる. OpenSNP は単なるッールではなく, 地域の情報プラットホームを担う 存在になるという設計思想から命名されている.

一般的にシステムの開発は, まず「開発仕様書」という詳 細な設計図を作成しておいてから，仕様書に従いプログラミ ングを行う。仕様がしっかりと詰まっているかどうかがその ままシステムの完成度や工期に影響を与える。しかし OpenSNP の開発は, 従来の常識とは異なっていた. 事前に 練り込まれた仕様があったわけではなく, 開発者と利用者が 対話をしながら機能を追加・修正してシステムの完成度を上 げる、いわば, オンデマンドユーザーオーダーメイド（利用 者の随時注文に即応した）開発手法となった。この方法は, 開発側がみると直接的には開発効率は高くはないものの, ニーズにあった機能が提供できるだけでなく，普段は閉じこ もり傾向にある開発者と利用者に一体感を持たせて, さなが ら「協働開発」を行うようなムードが双方に醸成される. 地 域 SNS エンジンとしての OpenSNP の完成度の高さは, この 開発者と利用者の良好な関係性に依拠するところが大きい.

約 3 ケ月の開発期間を経て, 2006 年 9 月に試用版が提供 されたひょこむは, 前述の開発者・ユーザ一体の開発手法に よって育まれ，続々と機能を追加するとともに，1 ケ月後の

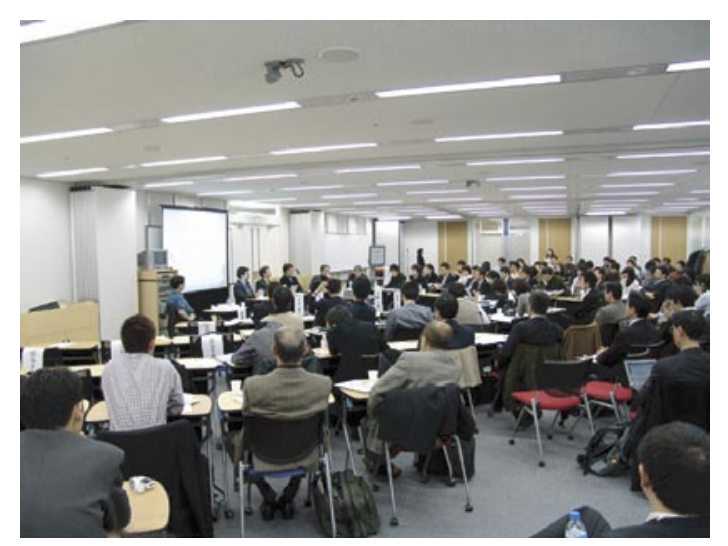

図 3 盛況だったCAN フォーラム「地域 SNS セミナー」 (2007. 01.27 に筆者が撮影)
正式稼働には利用者も当初の 3 倍強（約 353 名）となり, 着実に地域のキーパーソンたちを繋いでいった。

その後は, メンバ以外のユーザには存在も見えない「ステ ルスコミュニティ」や，発言やコメントがすべて実名で表示 される機能（実名コミュニティ）など，心地よい閉鎖性を自 由に作り上げることのできるコミュニティ管理, 発言者が外 部を含め公開範囲やコメント制御までできるアクセスコント ロール機能，そして，サイトが巨大になりすぎて地域 SNS が機能不全に陥ることを防ぎながら協調・分散するネット ワークを作る「のれん分け」など，これまで「煩わしい」と 検討することすら敬遠されていた，伝統的な日本型地域ネッ トワークを活かした関係性の仕組みを積極的に実装し, 成果 を挙げている.

\section{7. 地域 SNS 立ち上げと運用}

設計や開発だけでなく, 地域 SNS の開設準備や運用にお いても，日本型地域ネットワークの智慧は活かされた。地域 SNS の主宰者によると，地域における信頼関係にあるつな がりの連鎖の集合体である地域 SNS は， システムを設置・ 運用を始める段階で，その成長はある程度予測できるとい う。逆に，それだけ準備段階におけるデザインが重要である ことを意味する。筆者はこの点に着目して, 地域 SNS を立

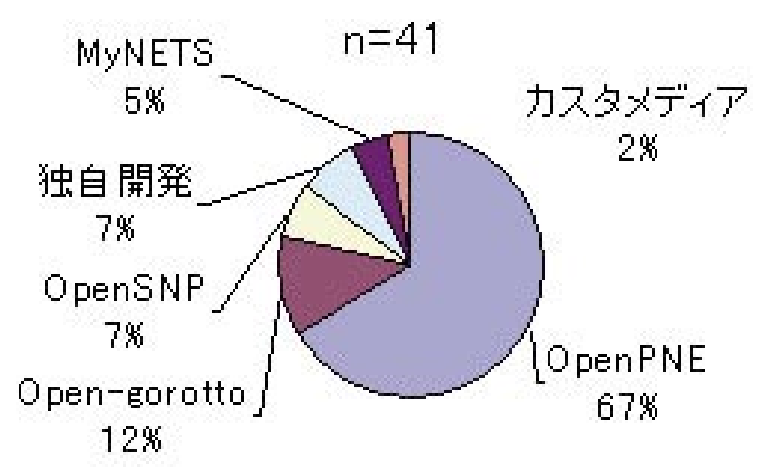

図４SNS エンジンのシェア分布（庄司，2008）

表 2 OpenSNP の主な開発履歴（筆者が作表）

\begin{tabular}{|c|l|}
\hline 年月 & \multicolumn{1}{c|}{ 主な開発内容 } \\
\hline 2006.06 & 開発着手 \\
\hline 2006.09 & $\begin{array}{l}\text { プレオープン. コミュニティマップ, 副管理人. } \\
\text { ランキング追加, 外部RSS 表示を実装. }\end{array}$ \\
\hline 2006.10 & 正式オープン. \\
\hline 2006.12 & モバイル (携帯) 基本機能実装. \\
\hline 2007.03 & グループ, コミュニティ外部公開機能実装. \\
\hline 2007.04 & 公認コミュニティ.モバイル拡張機能実装. \\
\hline 2007.05 & 実名コミュニティ実装. \\
\hline 2007.07 & 招待機能強化·メッセージ機能強化. \\
\hline 2007.08 & 地域通貨ポイント機能·SNS間連携機能 実装. \\
\hline 2007.10 & ブログ・モバイル·あしあと機能強化 \\
\hline 2007.12 & 動画機能試用版実装. \\
\hline 2008.04 & モ一ル試用版実装. 動画機能携帯対応版実装. \\
\hline
\end{tabular}


ち上げる前に心がけておかなくてはならないポイントを下記 のようにまとめた [8].

(1) 最初のメンバが色を決める

(2) スタートには助走が必要

(3) 熱い鍋を冷ましてはいけない

(4) 人数を追うと破滅につながる

(5) 完璧は成功の敵である

(6)いいかげんは良いかげん

(7) 主宰者自身がSNS の顔になる

(8) 地域であるメリットを十分に活かそう

(9) 実際に活動を行おう

(10) 地域 SNS は, 生活環境まで変える新時代のメディア になる

従来は連想すらされなかった伝統的地域ネットワークの要 素を ICT と融合させて設計・開発・運用を行っていると, その親和性の高さに気づく。これは, 2004 年に米国で発表 された「Web2.0」という新しいインターネット利用の概念 と, そのバックボーンのひとつとなっている「オープンソー 又開発」の理念と, 伝統的な日本型地域ネットワークの特徵 に通底するところが数多いからである.

運用においては, いくつかのユニークな具体的応用事例が ある。そののとつが「招待者承認」システムであり「後見制」 だ、それまでSNSは, 新しいメンバが参加する際に, 自由 に登録できるか，管理者が入会を承認するかの選択しかな かった，OpenSNPではこれに加えて，招待者が被招待者の 個人情報を確認して承認する機能を追加し, また歌舞伎の「後 見」に倣い，その招待者が被招待者の普段の世話やトラブル 時の仲裁などを行うこととした，招待関係双方の「絆」を常 に意識することの効果は, サイト内に扔けるふるまいにも好 影響があることが, 岩手大学総合情報処理センター吉田等明 准教授らの研究 [9] によって明らかにされている.

OpenSNP が日本型地域ネットワークのノウハウを利用 し，他のSNS エンジンに先馸けて設計や運用 ${ }^{11} に$ 活用した 主な内容は，下記の通りとなっている。

プロジェクト性 地域 SNS サイト連携, コミュニティ管理人連携, 実 名コミュニティ，インターネット TV 機能

自発性

トモダチ紹介機能, 仲人機能, コミュニティ管理機能

定日性

フォーラム・イベント・オフ会等の定期開催

柔軟性

メッセージへのファイル添付, 同報メッセージ機能, グループ管理機能, イベントカレンダー, コミュニティ マップ, ブログやコミュニテイ返信へのファイル添付

越境性

地域 SNS 間連携 API, のれんわけシステム, のれん 貸しシステム, コミュニティリンク機能, RSS 内外 相互対応, カーナビ連携機能, 外部公開コミュニティ
閉鎖性

完全招待制，後見人制，ステルスコミュニティ

その他

地デジ対応機能, SNS モール機能, 地域通貨ポイン 卜機能

\section{OpenSNP によるつながり活性効果の分析}

米国の社会学者ジェームズ・コールマンは著書『社会理論 の基礎』の中で「学歴や技能は個人に宿るが,ソーシャルキャ ピタルは関係に宿る」（1990）と述べている，社会的なつな がりは単に接続していることが大切なのではなく，その関係 性を相互扶助的かつ互恵的に育み，互いにタイムリーに助け 合える環境を成立させて, 場合によっては相互の持つネット ワークの力 (人脈) まで投入できる関係づくりを行うことが 重要である.

これを実現するには，地域 SNS がネット上で知り合った同 士が友好を深めて関係性を向上させるだけでなく，すでに認 知された関係にある人たちの関係性をより強く結びつけるこ とが求められる。この状況を確認するためにひょこむにおい て「利用者関倸性動向調査」を実施し, その結果を考察した.

「ひょこむ」では，知人や友人をサイトに招待したり，サ イト内でトモダチリンクを行う際に、リンク相手との[関係 の深さ）と［接触の頻度］を 5 段階で入力する。学術的な 分類ではないが,「関係の深さ」は「肉親・恋人」「親友・恩 師」「友人 ·同僚」「知人程度」「これから」，[接触の頻度 $]$ を「頻繁」「月イチ」「年イチ」「イマイチ」「これから」に分

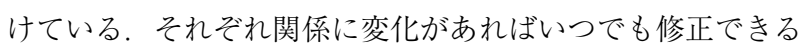
ようになっているが, サイトの利用に影響のない項目なの で，これまで当初に設定した後に変更された形跡はほとんど なく, 組み込んだ時点のつながり関係 (紐帯) が実質的に保 存されている.

この環境を利用して, 2008 年 8 月 26 日〜9月 2 日まで 8 日間，ユーザ全員にメッセージでWEB フォームによるアン ケート参加を呼び掛けた。調査は, 無作為に抽出された, 本 人とのリンクが成立してから 1 ケ月以上経過したリンク最 大 10 人まで対象として，［関係の深さ］と［接触の頻度］ の更新と行い, また関係性と接触頻度の変化を,「よくなっ た」「少しよくなった」「変わらない」「少しわるくなった」「わ るくなった」の 5 段階で, 回答を求めた。期間中に，ユー ザ総数約 4,200 人のうち 394 人 $(9.4 \%)$ が回答, 合計 3,103 のリンクについてデータを回収した.

[関係の深さ] では, リンクした当初は全体の約 $65 \%$ を占 めていた「これから」が約 $51 \%$ に減少している。これは, 好意的な交流が成立し関係性が深まっていることを示してい る(図 5)，最も強い「肉親・恋人」以外に招いて大幅に向 上していることを見れば，ひょこむが広く関係性の強化にあ る程度効果があったと言える.

[接触の頻度］で分かるのは，トモダチリンクをした時に 約 75\% は相手に会ったことがなく，ひょこむを利用してい 
る間に約 $53 \%$ に減少している（図 6)。これは「顔を合わせ られる距離感」を対象とする地域 SNS らしい現象で, 多数 のユーザが実際に出会う機会を持ったということである.「頻 繁」を除いて接触する頻度が増加しているが，「会わなくて も用務を遂げられる」情報通信ツールを使いながら, その実 体は逆に会う機会が全体として増えていることを示してい て，「とかくバーチャルに限定されているととらえられがち な ICT が,リアルな社会の関係性を補完する役割を担う」(和 崎）という地域 SNS の特徵が効果的に適用していることが わかる。

関係性と接触頻度には，ユニークな相関が見られた。 それ ぞれリンク当時のレベルを基準として, 相手との関係がどの 程度改善，または悪化したかについて分析をしてみると、リ ンク当時の「関係の深さ」によって特徴のある傾向は見られ なかったが, 概ね約 3 割のユーザが関係が改善されており, 地域 SNS を使っている間に悪化した関係は, どのレベルに おいても非常に少なかった（図 7)。また，十分に良好な関 係を維持していると思われる「肉親・恋人」において，更な る関係改善の傾向が見られるなど，ひょこむが人脈の構築・ 釀成に一定の効果を示していると言える。

接触頻度の変化では, リアルな交流の機会を示す接触頻度 が概ね 2 割前後が改善されており，会う機会が減少したと いう回答は少なかった（図 8).「年イチ」以上で定期的に会 う機会を持つ相手とは，ひょこむを利用することによって， その機会が多いほど頻度が増加する傾向がみられ，「頻繁」 に出会っていた相手との接触については，1／3が更に増加 したと回答している。これは，もともと良好なリアル関係に

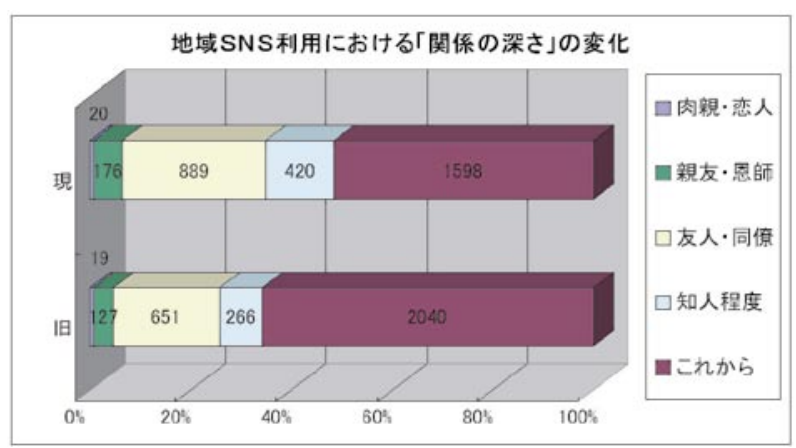

図 5 「関係の深さ」の変化 （筆者が作図）

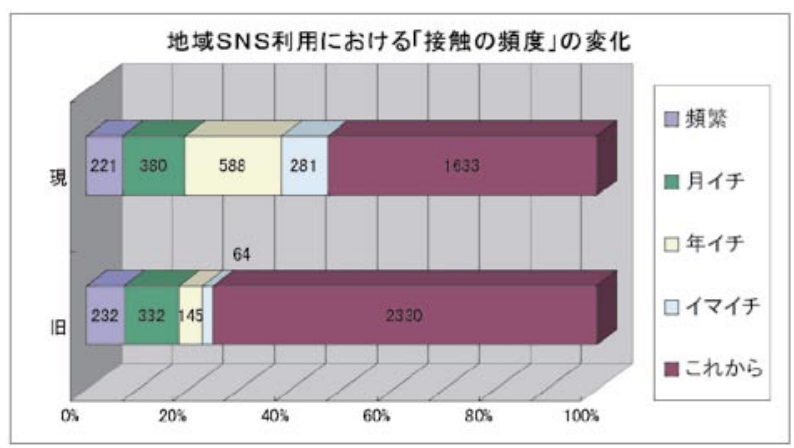

図 6 「接触の頻度」の変化 （筆者が作図）
あった相手とひょこむで接続することにより, サイトにおけ る擬似的な常時接続環境が, 日常的に相互の状態を可視化 し, 連携・協働の機会を増加させているものと考えられる.

この考察により，単にバーチャルなツールとして利用する ユーザより，実際に出会うことを通して交流を深めることが 関係性の向上に役立っており，一定数のユーザがそれを実施 していることが分かった，また，新しいつながりに対する効 果以上に, 既存の関係に対して良好な接続環境を提供してい ることも明らかとなった。 多くの地域 SNS サイトが, 開設 から一定期間はユーザ数が増加するのに，次第に新たな参加 者が減少して「踊り場現象」（和崎，2007）という停滞期を 迎えるのに対して, OpenSNPの各サイトはその傾向が小さ い(または起こっていない)。この分析で明らかとなったユー ザ個々によるつながりの可視化とそれを活性化するネット社 会とリアル社会の連携的活用が，サイト全体のにぎわいを継 続させる要素のひとつになっており, その基盤として ICT

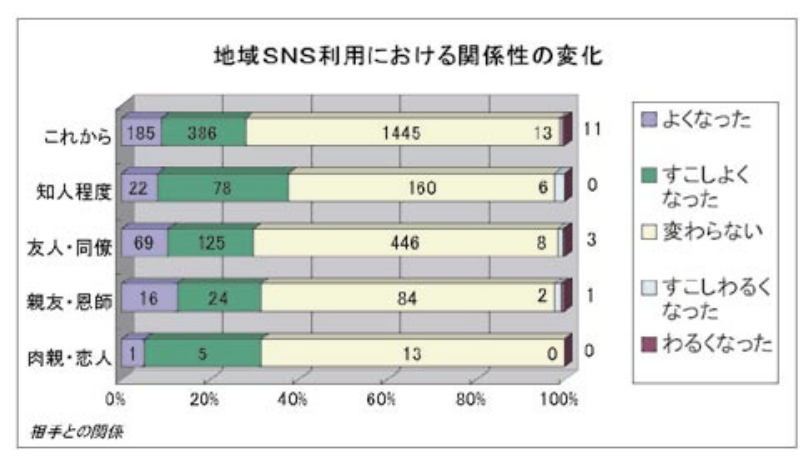

図 7 関係性の変化（筆者が作図）

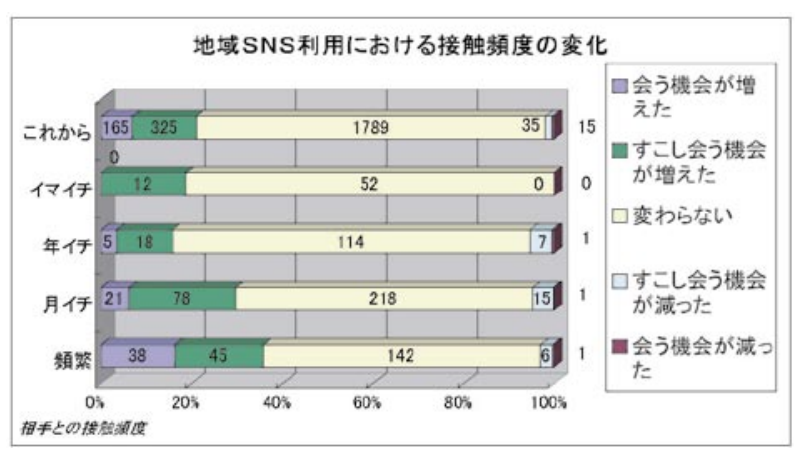

図 8 接触頻度の変化（筆者が作図）

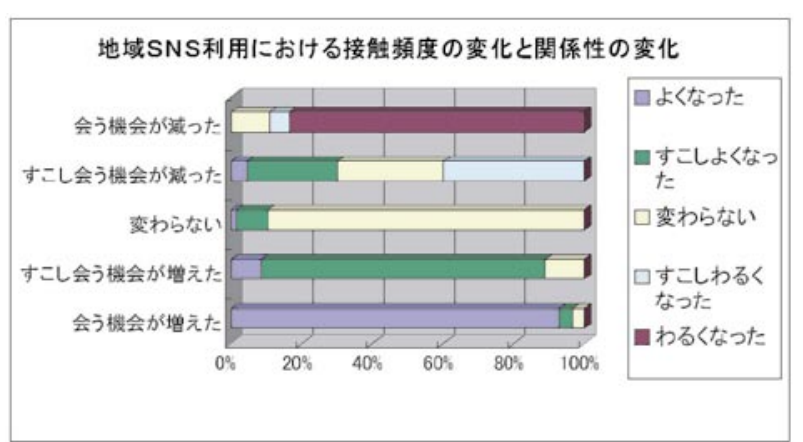

図 9 関係性と接触頻度の変化の相関（筆者が作図） 
と日本型地域ネットワークの融合が寄与しているものと考え られる。

\section{9. 創発の場としての情報プラットホームの創造}

日本型地域ネットワークの要素を取り入れた OpenSNP は, ひょこむでスタートした後, 2008 年 6 月現在, 館山（千 葉), 伊丹 (兵庫), 上田 (長野), 横浜 (神奈川), 宇都宮 (栃 木), 葛飾 (東京), 三田 (兵庫), 松江 (島根), 盛岡 (岩手), 佐用 (兵庫), 熊谷 (埼玉) の各地サイトで地域 SNS エンジ ンとして採用され，それぞれの地域独自の資源を活かしなが ら成長を続けている。また，岩手大学や関西学院大学では， 学内外のコミュニケーション基盤として実験が開始され, 世 田谷区や鎌倉などでは，団塊世代の社会参加や特別障がい支 援, 同郷つながりなどという特定テーマに特化した交流の場 としての活用が始まっている.

これらのサイトのほとんどは, 総務省の地域 SNS 間連携 API12を搭載している. 複数サイトに登録しているユーザ が主に利用しているサイトにログインすれば，他連携サイト の新着情報が自動的にチェックすることができる，連携 API は, OpenSNP だけでなく Open-gorottoにも対応しており, ユーザの負担が軽減されるだけでなく，サイト（地域）を越 えた人的連携のきっかけを生んでいる.

SNS 間連携は, ユーザの利便性やつながりの創出・強化 をもたらすだけではない。サイト運営者や開発者たちが積極 的に緩やかな「仲間ネットワーク」13をつくり, 運営や開発 の情報を活発に交流させている．松江と姫路の技術者たち が，それぞれの持つ携帯動画や PC 動画の実装技術を提供し あい, 通常なら $2 \sim 3$ 人月は楽にかかる工期を 3 週間程度に 抑えて, 携帯・PC 共用のインターネット TV 機能を世界で 初めて SNS に搭載したケースや, 横浜や盛岡の開発チーム が中心となって, OpenSNPをオープンソースとして公開す る ${ }^{14}$ 基盤技術を構築したり, 長野や熊谷のチームを中心に新 たな機能実装を協働で進めるなど, これまでの事例にはみら れない斬新かつ自発的で高度な技術連携が創発している.

このように「SNS は（ユーザと情報の）囲い込みで成立 する」という常識にとらわれずに，「越境性」を意識した運 用デザインを取り入れることにより，過去には想定できな かった新しい広がりと深まりを実現している.

「ほどよい閉鎖性を保つネットワーク」である地域 SNS で は，その中で展開されている出来事を外部から観察すること は非常に難しい．ログインして正規ユーザとして参加してい ても，サイト全体で何が起こっているのかを総括的に把握す るには, 大変な努力が必要だ。地域 SNS の効果について, まだ一般化された研究成果が出されていないのは, サイトの 多様性だけではなく，これまでの客観的参与観察では見えな い部分が多すぎるからであろう.

しかし現実に，地域 SNS の中では，ユーザ間及び場とし てのサイトとの「信頼」と地域への「愛着」を基盤として,

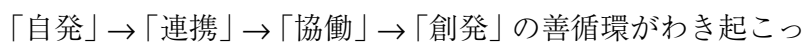

ている.ここでは, OpenSNPを採用する各サイトのエピソー ドをまとめた資料 ${ }^{15}$ から，いくつかの象徵的事例をピック アップする.

ひょこむには「デザインチーム」という主婦を中心にした 20 名ほどのグループがある. ウェブデザインを生業とする 女性達が，自発的に技術情報を交流し始めた勉強会だ，立ち 上がって間もない 2007 年 4 月，インフォミーム社に納車さ れた新しいバンが真っ白だったので，いたずらで「ひょこむ カーを作ろう」と投げかけたところ, 彼女たちが一気に盛り 上がった，次々とデザインシートが集まり，それをリーダー 役の男性（千葉県在住）がコーディネートしていく. 元来, ウェブデザイン仕事はチームでやるより個人で全ての工程を こなすことが多い．在宅ワークの彼女たちにとって，ネット を使った協働作業は初めての経験であったが，みんなの力で一 気に仕上がっていく作品に，それぞれ感激と感動を隠せなかっ たという。同年 8 月「第一回地域 SNS 全国フォーラム」 ${ }^{16}$ (神 戸）に拈いて，兵庫県公館の正面玄関に，ひょこむにおける 協働のシンボルとして完成した「ひょこむカー」が展示され, 来場者の注目を集めた。 バラバラだった在宅ワーカーたち が，これを機会に自信をもち，その後多くの仕事を連携・協 働で行っている.

地域 SNS では，よくオフ会と呼ばれるイベントが開催さ れ，メンバが実際に出逢う機会を作っている，元気なサイト では，コミュニテイ毎に自発的かつ突発的に行われることが 多いが, 運営側が全体に呼び掛けて比較的大きな集まりを定 期的に実施することも活発に行われている。ひょさむ゙は最 初の大規模オフは 2006 年 12 月のクリスマス会だった。「で きるだけ誰でも気軽に参加して楽しめるように」と，大学の 音楽堂を会場に借りて，飲み物や食べ物を持ちよるポトラッ ク制とした。自慢の一品を持参することで会話も交流も弾 む。そして参加費を集める必要もない，集まったのは 100 名近い人とモノだけではなかった。「子どもたちのために餅 つきをやろう」「楽器を持ち込んで演奏しょう」. いろんな特 技を持つ人たちが「勝手に」場を盛り上げてくれる。準備の プロセスを初動段階から公開することで「集合知」が顕在化 し「協働知」を産み出し, 新たな連携のモチベーションを高 めるのである。何度かメーリングリストを使ってこの方法を

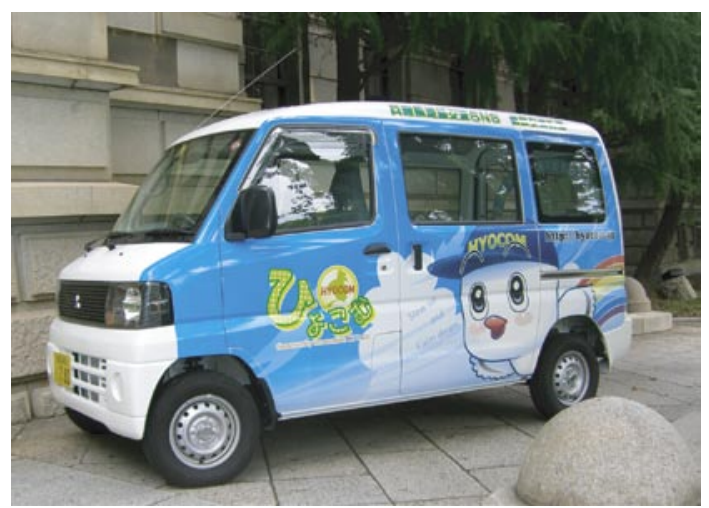

図 10 全国フォーラムに展示された「ひょこむカー」 (2007.08.31に筆者が撮影) 
採用していたが, 地域 SNS を基盤とすることで実施効果は 遙かに向上している。

地域 SNS と他メディアとの連携も活発だ。千葉県の「房 州わんだあらんど」ではコミュニティ FM と連動した「み なラジ」を開設したり, カーナビと情報連携させる企画を立 ち上げるなど, 積極的な取り組みを展開している. 盛岡の「モ リオネット」では, 2008 年 6 月 14 日に発生した「岩手 . 宮城内陸地震」において, さまざまなメデイアに流れる情報 を地域 SNS に集約し，コミュニティとブログを外部公開で 立ち上げ運用した。この迅速な対応は, 安否・医療・被害・ 対策など地域が必要とする各方面の情報交換に貢献した。こ れらの運用には, 新潟県中越地震の経験がある長岡の地域 SNS「おここなごーか」の指導も役立ったという．

地域 SNS の開発が縁でつながった松江と姫路の技術者た ちが, 互いの持つ映像処理技術を交換しあって, 動画処理で パソコンと携帯の垣根を払い共用できるシステムを完成させ

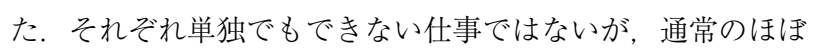
$1 / 3 \sim 1 / 5$ の工数で仕上げるという従来の開発手法では考 えられない程の効率を発揮した。本来囲い込まれる開発技術 や技術者本人を，信頼できる関係だから安心して自由に交流 させられる，その結果として大きな成果が得られるという象 徵的なケースだった。この事例と同様に, OpenSNPでは, 横浜·盛岡・上田・山形などの開発チームが協働して, 多数 の開発プロジェクトが進行している.

ロマンチックな話題もある. 名古屋と兵庫に暮らす縁もゆ かりもないはずのふたりの男女．掗い一度結婚生活に破れ て, 最愛の子ども達とも別れて暮らす境遇. ひょこむでの ちょっとしたコメント交換の機会が, 真面目な二人をいつし か引き寄せ合い，しばし遠距離を行き来する交際へと深まっ て, 祝福されてめでたく新しい家庭をふたりで創ることとな る. 信頼できる仲間たちに励まされながら愛を育み互いを確 認できたことは, きっと地域 SNS という温かい場の効果で あったに違いない.

このように地域 SNS の中では, ちいさなきっかけから生 まれた数えられないくらい多くの出来事が自律・自発的に発 生し, それらがひとりひとりのキーパーソンたちの連携を作 りだしている。繋がった人たちは, 信頼と愛着と常時接続状 態に近いネットワークを基盤として互いに情報交流を行い, 支援し合う関係になる．すると可視化されていく相互のネッ トワークを融合的に連携させた協働作業が見いだされること となり，新たなアクションが創発的に拡大するのである。こ の「場のにぎわい」こそが地域 SNS の活力であり, 安心で 心地よい雲囲気が新たなきっかけから出来事を生み出す原動 力となる。この循環が生活感 (Quality of life) の向上につ ながり，地域環境を高めていくのである.

\section{0. 地域 SNS の展開と展望}

OpenSNP では, 信頼性の高い地元のロコミ情報の坩堝で ある地域 SNS のコンテンッを, サイト外部にも積極的に提
供しようという動きが活発になっている，最初はブログやコ ミュニティを外部公開できるようにして，RSSを付けて外 部発信することから始まったが, 地域のインターネット TV として動画を流したり，カーナビや GPS 携帯などに位置情 報をつけて流すことで用途を広げたり，電子モールと連携さ せてビジネスニーズにも応えたりと多様だ。 08 年度には, ブロードバンド接続された地上波デジタル放送対応テレビに 郵便番号単位で地域情報を提供する基礎実験も始まり，その 可能性は更に拡大しょうとしている.

しかし，いかなる機能を追加しても，どれだけのメンバを 擁していても，「にぎわい」が感じられないサイトは持続可 能性が低い.一般的に SNS やグループウェアなどの交流型 サイトに扔けるにぎわいの指標は，一定の期間内にサイト内 で交わされるコミュニケーションの総和である.ページ ビューやデー夕転送量もひとつの目安とはなるが, ブログへ の投稿や返信, コミュニティへの発言やコメント，メッセー ジのやり取りなど, 可視化されたコミュニケーションが直接 ユーザ感じるにぎわい感となる。

しかし，各地域 SNS サイトのにぎわい度を分析するにお いて, 定期的にコミュニケーション総量を公開しているサイ トはほとんどない。そこでひょこむのコミュニケーションを 分析した（図 11）のグラフから，月次のコミュニケーショ ン総量と相関のあるとみられる「紐帯数」と「会員数」のう ち, 他のサイトでも状況が公開されている「会員数」の伸長 に注目することとした

全国各地の地域 SNS の中で, 参加者数が確認できた 46 サイトを継続調査した結果, 最近半年間で会員数の増加率が 高いサイトは（表 3）のようになった。 どの地域 SNS でも 開設から 3 ケ月から半年間は, 急激に会員が増加する傾向 が見られるので, 07 年 11 月に運用開始された盛岡・佐用・ 松江については割り引いて見る必要がある。この表からは, 運営主体が行政であろうと民間であろうとサイトのにぎわい にはあまり関係ないことがわかる，また，完全招待制や後見 制を採用しているサイトが上位を占めているところから， ネットワークの信頼を担保することが持続可能性を高める重 要な要素であることがわかる.

次に，実験段階も含めた立ち上げ 3 ケ月間に各地のサイ トがどのような伸びをしたのかをグラフにしたのが（図

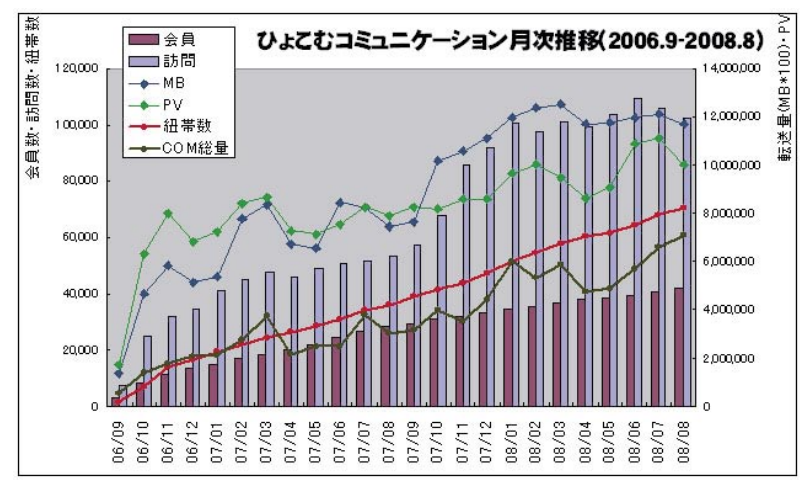

図 11 ひょこむのアクセス解析 （筆者が作図） 
12)である. どのサイトも 3 ケ月間で 250～300名前後となっ

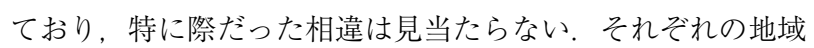
で拡大手法が異なるので一概には言えないが, 人口 360 万 人の横浜も, 30 万人の南房総も, 2 万人の佐用も, 立ち上 がりの段階は大きな違いはない。 これは人のつながりがその ままネットワークとして可視化され反映していく招待制のサ イトでは, 地方でも「強い紐帯」で繋がっている人脈を活か して, 大都市と変わりない立ち上げが可能であることを意味 する. 08 年 5 月に実験サイトを開いた熊谷 (埼玉)では,「う ちわ祭」という地域あげての祭りの人脈ネットワークが繋 がって僅か 60 日あまりの間にメンバが 300 人を越え, 活発 な交流が始まっている。地域 SNS の立ち上げにおいては, そのエリア規模に注目しすぎずに,「強い紐帯」で繋がって いる実際の地域活動のネットワークと, SNS サイトの「弱 い紐帯」の融合を図ることで，より順調に成長させることが 可能になると考えられる.

\section{表 3 地域 SNS の会員伸長（08 年 01 月 01 日 -07 月 01 日） (筆者調査により抜粋して作表)}

PNE : OpenPNE/SNP : OpenSNP/GRO : Open-gorotto/ $O R G:$ 独自ソフト

\begin{tabular}{|c|c|c|c|c|c|c|c|}
\hline 地域名 & 設置 $/$ 運営 & $08 / 01$ & $08 / 07$ & $\begin{array}{c}\text { 伸長 } \\
\text { 率 }\end{array}$ & $\begin{array}{c}\text { 入会 } \\
\text { 方法 }\end{array}$ & $\begin{array}{c}\text { 承認 } \\
\text { 制 }\end{array}$ & $\begin{array}{c}\text { ジン } \\
\text { ジン }\end{array}$ \\
\hline 盛岡 & 行政 $/$ 官民 & 169 & 581 & 3.44 & 招待 & 後見 & SNP \\
\hline 佐用 & 行政 $/$ 官民 & 142 & 335 & 2.36 & 招待 & 後見 & SNP \\
\hline 松江 & 行政 $/$ 行政 & 213 & 461 & 2.16 & 招待 & 後見 & SNP \\
\hline 横浜 & 官民 $/$ 民間 & 837 & 1527 & 1.82 & 招待 & 後見 & SNP \\
\hline 三田 & 民間 $/$ 民間 & 167 & 272 & 1.63 & 招待 & 後見 & SNP \\
\hline 伊丹 & 高校 $/$ 高校 & 575 & 881 & 1.53 & 招待 & 後見 & SNP \\
\hline 上田 & 大学 $/$ 大学 & 410 & 565 & 1.38 & 招待 & 無し & SNP \\
\hline 千葉 & 民間 $/$ 民間 & 1959 & 2620 & 1.34 & 招待 & 無し & PNE \\
\hline 福岡 & 行政 $/$ 行政 & 523 & 676 & 1.29 & 招待 & 無し & ORG \\
\hline 京阪奈 & 民間 $/$ 民間 & 159 & 203 & 1.28 & 自由 & 無し & PNE \\
\hline 葛飾 & 官民/民間 & 444 & 543 & 1.22 & 招待 & 後見 & SNP \\
\hline 掛川 & 行政 $/$ 行政 & 1180 & 1425 & 1.21 & 自由 & 無し & GRO \\
\hline 兵庫 & 民間 $/$ 官民 & 3322 & 3995 & 1.20 & 招待 & 後見 & SNP \\
\hline
\end{tabular}

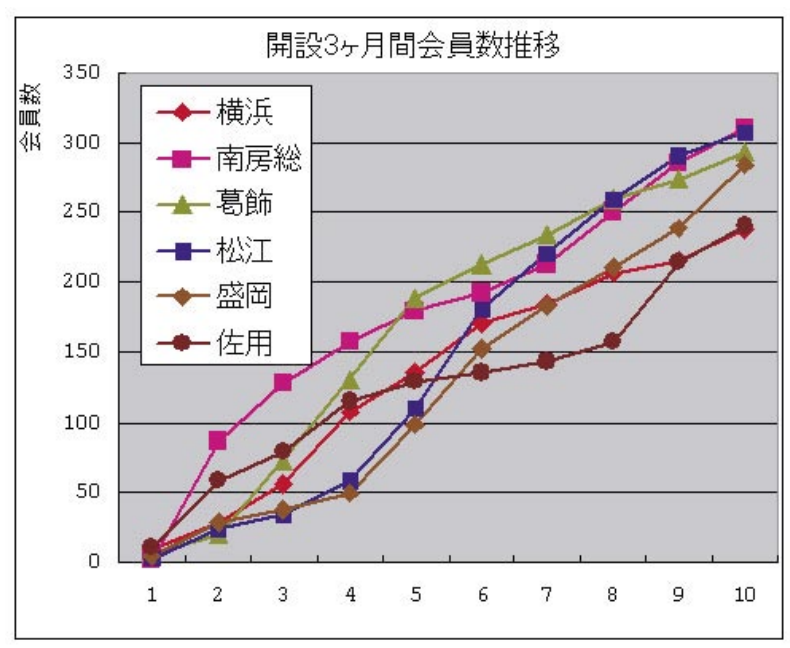

図 12 地域 SNS の会員数推移（実験期間を含む） （筆者が作図）

\section{1. 最 後 に}

地域情報化という言葉が使われ始めて 30 年. 巨額の投資 を繰り返してきた政府の開発主義的な政策だけでなく, 80 年代の草の根 BBS や商用 BBS というパソコン通信を使っ たコミュニケーションの試みや 90 年代のインターネットに よるさまざまなアプリケーションの活用に至るまで, 開発に 携わる技術者たち共通の悩みは, 情報化ツールの効果が地域 に浸透しないことだった。夜新しいテクノロジーを取り入 れ，地域ニーズを捉えたシステムを設計し投入する彼らの努 力は, 皮肉にも「すべてを情報技術で解決しょう」という傲っ た開発思想による現場とのミスマッチが起こしたジレンマに よるところが大きかった。

01 年 10 月, 日本で最初の電子地域通貨「千姫」の運用を 開始した岡田真美子 ${ }^{17}$ は, インターネットや携帯から利用 できるシステムとして,メニュー表・掲示板・コメント付き 取引という非常にシンプルな大福帳式プログラムを採用し た.この仕組みはのちのち参加者のニーズによって成長し, 同時に利用者のモチベーションもあがっていった。岡田は当 時から「完璧なシステムを求めずに，十分に人の絆の持つ力 を活用することで，システムも人も育っていく」と語り，従 来とは異なる開発手法を取り入れて地域情報化の世界に新た な方法論を提案した。 あえて「人」がかかわる部分を明示す ることによって，システムと人材が相互に支え合い活かされ る共育の関係がデザインされていた.

本論で示すように, 地域住民の関係性を活性化することを 目的とする地域 SNS の設計や運営には, ICT と伝統的な日 本型地域ネットワークの知見を融合的に取り扱うことの重要 性が, OpenSNPの展開によって明らかとなった。その過程 では,「ネットワークはオープンであるべき」や「参入障壁 は低い方がよい」とか「効率的に運用すべき」などという， 従来のシステム設計やサイト運営に扔いて定説や常識として 考えられていたのとはまったく逆のアプローチ,すなわち「ほ どよい閉鎖性を保つネットワーク」「完全招待や後見制とい う敷居の高い加入手続き」「何事も環境が整うまで十分な時 間をかける」ことなどがしばしば有効であった。これには, 情報工学, 社会学, 民俗学, 複雑系など, 多様な先行研究を 学際的に取り扱い, 新たな関係性価值創造の手法を見いだす 感性工学的な考察が活かされた。

OpenSNP は，持続可能な地域 SNS エンジンであるだけ でなく, 地域のネットワークが持つ潜在した関係性の力を可 視化し活用することで, 科学技術や経済的手法では埋められ なかった多様な社会の隙間や歪みを埋めるきっかけを作るこ とができる.また, 急速に弱体化しつつある地域のエンパワー メント（地域力）を覚醒させることも可能である。「ほどよ い閉鎖性を保つネットワーク」が, 地域の枠を越えて連携・ 協調することにより，都会だけでなく人口の比較的少ない郡 部においても, 地域固有のコミュニテイ活動の活性化を誘発 しながら，まちを元気にする原動力として役立てることがで きる。 
今後, 地域 SNS は, 限定した交流型サイトとしての役割 はもちろんのこと, さまざまな地域の信頼できるクチコミ情 報をコンピュータ以外の多様なチャンネルを通じて多数の住 民が共有する「情報プラットホーム」として成長をしていく ことが期待される，そうなれば，地域内に抢ける情報の循環 が促進されることによって，これまで一極集中していた情報 の流れが徐々に変化して「情報の地産地消 ${ }^{18} 」$ (和㟝) が実 現し, 人材流出・経済疲弊 - 少子高齢化などの地域課題を解 決するコミュニティの社会基盤創造の可能性が視野に入って くるに違いない.

\section{参 考 文 献}

[1] 岡田真美子：地域をはぐくむネットワーク, 昭和堂, 8, 2006

[2] 牧慎太郎 : 知縁コミュニティと地域 SNS の展開, 月刊自 治フォーラム 2 月号, 自治大学校, pp.25-32, 2008

［3］４4］［5］庄司昌彦：地域 SNS サイトの実態把握, 地域活 性化の可能性, 情報通信政策研究プログラム, pp.15-16, 18, 2008

[6] 国領二郎：地域情報化認識と設計, NTT 出版, pp.145-146, 2006

[7] 岡田真美子：地域づくりと実践的学問一地域ネットワーク の継承と再生を目指して, 日本の空間学, 東信堂, pp.135-136, 2008

［8］和㠃宏：地域 SNS 最前線 -Web2.0 時代のまちおこし実践 ガイド, アスキー, pp.177-179, 2007

[9] 吉田等明 : オンラインでの匿名性と倫理観, コンピュータ＆ エデュケーション vol24, 東京電機大学出版局, pp.20-25, 2008

\footnotetext{
${ }^{1}$ SNS エンジンとは, SNS システムの基盤プログラム. OpenSNPは, 'open social networking platform’ の略.

2 考察に扔いては, 開発者かつ運営管理者として「ひょこむ」, 共同運 営管理者として「三田」「伊丹」「熊谷」「横浜」「葛飾」「佐用」「南房総」 (以上は管理権を持つ), 運営チームメンバとして「上田」「盛岡」, 運 営顧問として「松江」「栃木」, また一般ユーザレベルでその他 33 サ イト(計46サイト)の参与観察を行った.

3 1999年に設立された匿名揭示板群で, 利用者が自由にボードを設 置できることから急成長し, ネット社会の荒廃の代名詞化されるこ とが多い

${ }^{4}$ OpenSNPでは, 最初の適応サイトとしてのひょこむを, 機能開発や システム運用のテストベッドとして利用している，ひょこむは，招 待制では日本最大の地域SNSサイトとなっている(2008年8月現在).

5 兵庫県が平成 19 年度から継続して実施している「地域 SNS 活用実
}

証実験事業」. 平成 20 年度はワンセグ地域放送局と地域SNS の連 携を実施．全体では700名近い県職員が実験参加しいている.

6 神戸・横浜で開催された「地域SNS 全国フォーラム」のセッション において, 複数のSNS 運営者により同様の発言があった.

7 ひょこむの「ひょこむ塾」, モリオネットの「ブドリーズ」, かちねつ との「かちねっと広場」などは, 技術サポートだけでなくユーザの コミュニケーション相談の場になっている.

8 セミナーに関する内容が報道されているニュース記事は, http://www.itmedia.co.jp/news/articles/0601/27/news118.html

9 この時, 八代市の「ごろっとやっちろ」をべースとしたOpen-gorotto と, (有) 手嶋屋が提供する OpenPNEという二つのオープンソース が利用されていた，オープンソースは無料でプログラムが入手で きる利点はあるものの, その修正や改造には独自で開発する以上 の作業工数が発生することが難点である.

${ }^{10}$ (財) 地方自治情報センターが開発した「地域SNS 間連携API」に対応.

${ }^{11}$ openSNPで実装した機能は, 他のSNS エンジンに扔いてその後採 用されていくものが多い.

${ }^{12} \mathrm{http} / / / \mathrm{www}$. lasdec.nippon-net.ne.jp/rdd/community/h19koubo/ h19yoryo_ecom2_bt.pdf

${ }^{13}\lceil$ OpenSNP developers party」というグループを作って, 常時情報 交換を行い協働プロジェクトを推進している.

${ }^{14}$ 段階別に 2008 年 9 月と 2009 年 3 月にわけて, オープンソースプロ グラムとして一般公開の予定.

15 詳しい資料は, http://opensnp.jp/episode1.pdf

16 フォーラムの模様は, 下記にレポートされている. http://itpro.nikkeibp.co.jp/article/COLUMN/20070913/281853/

${ }^{17}$ 兵庫県立大学環境人間学部教授

${ }^{18}$ 地域情報が地域内で循環するデザインを構築することにより，ヒ ト・モノ・カネにも地域で循環するシステムができあがるという考 え方. 1980年代後半から90年代前半にかけて, 米国シリコンバレー の復興を支えたJoint venture way (ジョイントベンチャー方式)は, 情報化によって潜在化していたインフォーマルなネットワークを 可視化することで, ソーシャルキャピタルの活性を促し, 地域の経 済·文化·教育·生活環境の向上を実現したモデルである。

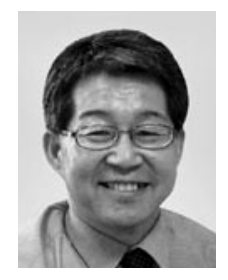

和崎 宏 (学生会員)

1957 年 12 月 22 日福岡県生れ インフォミー 么株式会社代表取締役. 80 年琉球大学理学 部卒. 04 年兵庫県立姫路工業大学大学院環 境人間学研究科にて修士課程を修了. 現在, 兵庫県立大学大学院環境人間学研究科博士後 期課程在籍中. 日経地域情報化大賞 2004(CANフォーラム賞), 平成 16 年度地域づくり総務大臣表彰, 日経地域情報化大賞 2008 （グランプリ）を受賞. 07 年から, 総務省地域情報化アド バイザー，共著に「地域 SNS 最前線－Web2.0 時代のまちおこ し実践ガイド」(アスキー),「地域をはぐくむネットワーク」（昭 和堂）などがある. 